\title{
Multi-indicator building vulnerability index for assessing tsunami-induced building damages
}

\author{
Mohd Muhaimin Ridwan Wong ${ }^{1,2 *}$, Nordila Ahmad ${ }^{2}$, Syamsidik $^{3}$, Anawat Suppasri ${ }^{4}$, and Maidiana Othman ${ }^{2}$ \\ ${ }^{1}$ Humanitarian Assistance and Disaster Relief Research Centre, National Defence University of Malaysia, Kem Perdana Sungai Besi, \\ 57000 Kuala Lumpur, Malaysia \\ ${ }^{2}$ Department of Civil Engineering, Faculty of Engineering, National Defence University of Malaysia, Kem Perdana Sungai Besi, \\ 57000 Kuala Lumpur, Malaysia \\ ${ }^{3}$ Tsunami and Disaster Mitigation Research Centre (TDMRC), Jalan Professor Doktor Ibrahim Hasan, Ulee Lheue, Meuraxa, Kota \\ Banda Aceh, 23232 Aceh, Indonesia \\ ${ }^{4}$ International Research Institute of Disaster Science (IRIDeS), Tohoku University, 468-1 Aoba, Aramaki, Aoba-ku, Sendai, Miyagi, \\ Japan 980-8572
}

\begin{abstract}
While relatively uncommon, tsunami typically leads to extreme and devastating impacts to human lives and development at far distances. Various international bodies and academic research have highlighted the importance of understanding risk and its determinants for effective risk management. Currently available methodologies to assess tsunami risk and the effect of vulnerability towards the resulting impact present opportunities for improvement particularly in their adaptability, accuracy and generalisability for pre- and post-disaster applications, as well as across temporal and geographical boundaries. This paper discusses the potential of a methodology to assess tsunami risk for buildings based on their vulnerability level, which in turn is determined through a set of vulnerability indicators. A vulnerability index equation consisting of four indicators namely building materials, number of storeys, coastal protective structures and coastal vegetation was formulated through the Analytical Hierarchy Process. The index is then applied for two major yet distinctly different tsunami events for the purpose of examining potential links between hazard intensity measure, building vulnerability and recorded impacts while also establishing basis for generalisability. While certain correlations can be observed, the findings are still at preliminary stage and thus approaches to further refine the index were proposed.
\end{abstract}

\section{Introduction}

For the last two decades, 271 tsunami events have been recorded resulting in over 300,000 casualties associated directly with these tsunami disasters [1]. Major tsunami events such as the 2004 Indian Ocean tsunami, 2010 Chile tsunami, 2011 Japan tsunami and the 2018 Sulawesi tsunami accounted for majority of these casualties. Aside from casualties, these tsunami disasters also caused major losses and setback due to properties and infrastructure destruction as damages amounted to billions of dollars in some cases. The 2011 Japan tsunami resulted in approximately US $\$ 220$ billion of damages (US\$37.5 billion of which were insured), while the February 2010 Chile tsunami disaster incurred damages up to US\$30 billion (with US\$8 billion damages insured) [1,2].

An important approach in reducing disaster risks and impacts including for tsunami inarguably lies in understanding these risks, their determinants and how they revolve around and interact with all aspects of anthropogenic development. The United Nations Office for Disaster Risk Reduction (UNDRR) strongly advocates for effective and comprehensive disaster risk management achievable through understanding disaster risk drivers which consist of hazards, exposure and vulnerabilities [3]. Subsequent to understanding these risk determinants, impacts both direct and indirect, tangible and intangible, can be better managed via various preparedness and mitigation strategies.

In line with the above concept, tsunami studies over the past several decades have also been advancing our understanding on tsunami hazard and its impacts. Quantification of tsunami magnitude and intensity had begun since early in the $20^{*}$ century as Sieberg introduced the first tsunami intensity scale, and this was followed by many other variations based on tsunami events across the globe. More recently, in addition to tsunami intensity models, this effort to improve and communicate the understanding of tsunami hazards and its impacts have been broadened as more approaches are made available. Such approaches include probabilistic risk models [4-6], deterministic impact framework [7], multi-hazard impact models $[8,9]$, vulnerability assessment models $[10,11]$, and tsunami loss estimation models $[12,13]$.

Despite these developments, most tsunami risk and impact assessment methodologies or models remain specific and more relevant to certain geographical scope or tsunami event. Others that are more generalisable can

\footnotetext{
* Corresponding author: waiminwong86@gmail.com
} 
be constrained in application as well as in correlating between different tsunami risk determinants and observable impacts. The main aim of this paper is to offer a preliminary discussion of a tool to assess building vulnerabilities against tsunami hazard with varying magnitudes, as well as relate these variables to potential damages that can be observed. Thus, presented in this paper are also attempts at addressing two research questions formulated based on the primary aim. The first of these is that considering well-known and established vulnerability and/or risk indicators in literatures, which indicator can be measured and used universally particularly as components of a vulnerability index? Secondly, how does the combination of these vulnerability indicators affect severity of building damage based on past tsunami events with different triggering mechanisms? The first question is answerable by identifying and defining vulnerability indicators and their associated proxies that are relevant to buildings or structures from past research and tsunami field survey. On the other hand, the second research question can be addressed by reviewing field survey data from previous tsunami events, through which a measurement of tsunami hazard intensity is correlated with observed damages via a proposed, moderating building vulnerability index.

\section{Tsunami vulnerability indicators}

While hazardous events may have been traditionally believed to be the sole or primary factor for disaster risks, the current state of knowledge requires two other determinants as components that make up the concept of risk, viz. vulnerability and exposure [14]. Exposure can be defined as elements potentially experiencing damages and/or losses in at-risk areas where hazard event may occur [15]. These elements can usually be identified based on satellite images, city plan or aerial photos, and may be categorised based on different degree of exposure to predicted or historical events. Meanwhile, as a term that has been more common in disaster research since the $1980 \mathrm{~s}$, vulnerability was generally used in reference to systems in a geographical region or locality including socio-political, socioeconomic and industrial practices [16]. Presently, vulnerability can be more accurately identified in reference to characteristics of exposed elements or attributes in their proximity that may influence their susceptibility to adverse effects following interactions with hazard events [14].

In relation to earlier views, vulnerability characteristics may indeed be derived from physical, environmental, economic, social, and political settings. From a macro-perspective lens, vulnerability can be identified in the form of population growth, rate of urbanisation, governance, economic disparity and environmental degradation, among others [17]. However, in the context of this paper where buildings are concerned, various tsunami vulnerability indicators, parameters and/or their proxies have in fact been identified and widely established at micro level in various studies previously. Commonly used vulnerability indicators include building typologies, construction materials, number of stories, building design code, building age, and building geometry $[9,18-$ 21]. Among presently available methodologies, the Papathoma Tsunami Vulnerability Assessment (PTVA) is one of the more comprehensive method with inclusion of various building vulnerability and building surrounding attributes as part of its structural vulnerability component, $S_{v}$ [11]. Aside from aforementioned indicators, PTVA via its building vulnerability attributes (BV) proposed inclusion of ground floor hydrodynamics, foundation type, and preservation condition. For building surroundings attributes (denoted as Surr), building row, natural barriers, seawall height and shape, brick walls around the building, and sources of movable objects were proposed for inclusion as well. In addition to these parameters, level of water intrusion and exposure to inundation also make up the Relative Vulnerability Index (RVI) equation. For assessment, the vulnerability index is then calculated based on weightages assigned subjectively to each of the attributes. Two distinct group of vulnerabilities are described further in the following sub-sections in connection to the topic of this paper.

\subsection{Building characteristics}

Based on past studies and impact assessment methodologies such as the Hazards U.S. Multi-Hazard (HAZUS-MH) and RISK-UE, assessment of a building's vulnerability against tsunami via its characteristics may include one or more of the following factors:

a. Building materials, also identifiable as construction materials or building frame: usually classified based on the primary materials that make up the structure to distinguish different strength to withstand tsunami loading, viz. timber, masonry, concrete (reinforced or non-reinforced), and steel.

b. Number of storeys: multi-storey buildings are typically designed to be more resistant to external forces compared to single-story buildings. Classification is typically done based on literal number of storeys, or in some cases the number of storeys may be grouped in ranges and buildings are then categorised as low-rise, medium-rise or highrise.

c. Foundation type: used as an indicator of foundation strength and in turn the building's resistance against damages resulting from scouring effects by tsunami inundation. A structure may resist the initial punching force caused by tsunami flow inland, but evidence from past events showed that scouring at the base often lead to the structure being collapsed, broken or washed away especially where foundation is shallow [22, 23].

d. Geometry: may refers to the shape of the structure or its elements, span lengths as well as orientation relative to tsunami wave direction [24].

e. Design code: as a parameter that can be used to differentiate design specifications or standards for the buildings assessed. Particularly in developed 
countries prone to disasters, most buildings tend to be designed and constructed to be resistant to disaster hazards and induced lateral loads. While this may be specific towards seismic hazard, the classification has been applied in tsunami studies as well [18].

f. Building age and preservation condition: similar to other physical parameters that make up a building typological features, building age can be used as reference to characterise its vulnerability to hazard events with aged buildings typically being more vulnerable. Additionally, preservation condition could help further distinguish the state of deterioration of aged buildings and thus variations in its level of vulnerability.

\subsection{Building proximity}

Environmental characteristics, structure and conditions in the relatively nearby vicinity of the building can directly or indirectly affect its vulnerability. Identified and commonly used characteristics associated with tsunami vulnerability and/or fragility include:

a. Protective structures, also referred to as sea defence: this parameter refers to identifiable structural mitigation (engineered or otherwise) against coastal hazards, with seawalls being the common coastal defence structure in tsunami-prone areas. In areas where tsunami is much less frequent, coastal protection structures such as levees, revetments and embankments may still protect exposed buildings and reduce their vulnerabilities particularly for tsunami with lower inundation depths [25].

b. Coastal topology, also identifiable as coastal topography: the type of the coastal area evidently has major influence on tsunami inundation and flow velocity, particularly for buildings closer to the shoreline. Buildings along ria-type coasts are more vulnerable and have higher damage probabilities (at similar inundation depths) than those in low-lying plains $[4,26]$.

c. Coastal vegetation: various studies have found that coastal vegetation and forests are able to dampen tsunami effects and reduce its runup through energy dissipation and wave-breaking capabilities [27]. Parameters related to coastal vegetation affecting tsunami vulnerability include band width (between shoreline and exposed elements), density, species composition, forest structure, age and height, among others [28].

\section{Methods}

Three approaches are considered to appropriately address questions posed earlier in this paper. The aim as framed based the questions is to formulate a building vulnerability index that can be utilised to categorise buildings (as exposed elements in at-risk areas), and subsequently identify potential correlations between hazard intensity, vulnerability levels and impact intensity. The first approach is the identification of vulnerability indicators and measurement parameters that are most suitable for a universally applicable assessment tool. Following this, the Analytical Hierarchy Process (AHP) is utilised to express the basis of the vulnerability index with appropriate priority weightages assigned for each vulnerability component. Thirdly, the vulnerability index is applied to two tsunami events (with different triggering mechanisms) for the purpose of identifying the relationship that can be observed between all risk determinants involved.

\subsection{Vulnerability indicators and measurement parameters}

In comparison to the methodologies presented through other comprehensive and more complex methodologies such as PTVA or Building Vulnerability Model (BTV) [29], this paper contends that a simplified assessment tool with generalisable components and measurement may be more practical and applicable especially for a wider risk communication purpose, as well as both exante and post-disaster assessment utilisations. In addition, data limitations and discrepancies in data recording between different tsunami events may also pose challenges for effective application of more complex tools. Hence, in order to attain this generalisability and practicality, established indicators and/or measurement parameters as briefly described in 2.1 and 2.2 are screened for inclusion in a newly proposed index. The variables, measurement parameters and justification for selection are listed in Table 1.

\subsection{Building vulnerability index}

For assessment of building vulnerability, the Analytical Hierarchy Process or AHP was employed to formulate the index equation. As a mathematical process, AHP is a heuristic algorithm that involves arranging factors in a hierarchy of importance [33], whereby for this paper the context is the indicators' influence and effectiveness in reducing tsunami damage. Levels of importance are normally represented numerically between 1 (least important) to 9 (most important), depending on the quantity of indicators being considered. The indicators are then compared pairwise, and the priority vectors (PV) as calculated based on this comparison are used as the weightage for each indicator. Being the first line of defence, protective structures are designated as the most important indicator, followed by coastal vegetation, building materials and lastly the building's number of storeys. This subjectively assigned hierarchy are shown in Table 2, while the pairwise comparison and the resulting priority vectors are shown in Table 3. 
Table 1. Selected vulnerability indicators and measurement parameters.

\begin{tabular}{|c|c|c|}
\hline Indicator & $\begin{array}{c}\text { Measurement } \\
\text { parameter }\end{array}$ & Justification \\
\hline $\begin{array}{l}\text { Building } \\
\text { materials } \\
(\mathrm{BM})\end{array}$ & $\begin{array}{ll}\text { Four categories: } \\
\text { i. } & \text { Timber } \\
\text { ii. } & \text { Masonry } \\
\text { iii. } & \text { Steel } \\
\text { iv. } & \text { Reinforced } \\
& \text { concrete }\end{array}$ & $\begin{array}{l}\text { This indicator and its } \\
\text { parameters are } \\
\text { among the most } \\
\text { commonly used, and } \\
\text { well-established in } \\
\text { their relationship and } \\
\text { influence towards } \\
\text { observable damages. }\end{array}$ \\
\hline $\begin{array}{l}\text { Number of } \\
\text { storeys (St) }\end{array}$ & $\begin{array}{l}\text { Three categories: } \\
\text { i. } 1 \text { storey } \\
\text { ii. } 2 \text { storeys } \\
\text { iii. More than } 2 \\
\\
\text { storeys }\end{array}$ & $\begin{array}{l}\text { While there are } \\
\text { variations in the } \\
\text { measurement } \\
\text { parameters in past } \\
\text { studies, the number } \\
\text { of storeys considered } \\
\text { in this paper is } \\
\text { limited to the three } \\
\text { categories. This } \\
\text { categorisation is also } \\
\text { supported by } \\
\text { evidence from } \\
\text { analysis of building } \\
\text { damages during the } \\
2011 \text { tsunami in } \\
\text { Japan [4]. }\end{array}$ \\
\hline $\begin{array}{l}\text { Protective } \\
\text { structures } \\
\text { (PS) }\end{array}$ & $\begin{array}{l}\text { Four categories: } \\
\text { i. None } \\
\text { ii. } \\
\text { Breakwater } \\
\text { only } \\
\text { iii. } \\
\text { Presence of at } \\
\text { least one hard } \\
\text { protection } \\
\text { (seawall, } \\
\text { revetment } \\
\text { etc.) } \\
\text { iv. } \\
\text { Combination } \\
\text { of more than } \\
\text { one coastal } \\
\text { protection } \\
\text { structure } \\
\text { (breakwater, } \\
\text { seawall, } \\
\text { revetments } \\
\text { etc.) }\end{array}$ & $\begin{array}{l}\text { Past studies have } \\
\text { found that in areas } \\
\text { where low seawalls } \\
\text { and/or revetments } \\
\text { are present, } \\
\text { buildings landward } \\
\text { were protected to } \\
\text { some degree } \\
\text { particularly in non- } \\
\text { extreme tsunami } \\
\text { events [23]. Tsunami } \\
\text { inundation and its } \\
\text { impacts have also } \\
\text { been observed as } \\
\text { much lesser in such } \\
\text { area compared to } \\
\text { non-protected areas } \\
\text { [25]. } \\
\text { On the other hand, } \\
\text { another study } \\
\text { concluded that } \\
\text { breakwater does not } \\
\text { offer significant } \\
\text { protection to coastal } \\
\text { buildings mainly due } \\
\text { to openings between } \\
\text { sections of the } \\
\text { breakwater [30]. }\end{array}$ \\
\hline
\end{tabular}

\begin{tabular}{|c|c|c|}
\hline Indicator & $\begin{array}{c}\text { Measurement } \\
\text { parameter }\end{array}$ & Justification \\
\hline $\begin{array}{l}\text { Coastal } \\
\text { vegetation } \\
(\mathrm{CV})\end{array}$ & $\begin{array}{ll}\text { Three categories: } \\
\text { i. } & \text { None } \\
\text { ii. } & \text { Band width < } \\
& 200 \text { meters } \\
\text { iii. } & \text { Band width } \geq \\
& 20 \text { meters }\end{array}$ & $\begin{array}{l}\text { Despite the } \\
\text { availability of } \\
\text { multitude of factors } \\
\text { affecting wave } \\
\text { attenuation in } \\
\text { literature, the three } \\
\text { categories were } \\
\text { selected upon } \\
\text { considering } \\
\text { practicality, ease of } \\
\text { data collection } \\
\text { and/or limitations in } \\
\text { data availability. } \\
\text { The measurement } \\
\text { parameters were also } \\
\text { determined based on } \\
\text { past studies on the } \\
\text { different effective- } \\
\text { ness for different } \\
\text { coastal forest band } \\
\text { width towards } \\
\text { tsunami reduction } \\
\text { [31, 32]. }\end{array}$ \\
\hline
\end{tabular}

Table 2. Preference for each vulnerability indicator based on level of importance to reduce tsunami damage.

\begin{tabular}{|c|c|c|}
\hline Value & Level of importance & $\begin{array}{c}\text { Vulnerability } \\
\text { indicator }\end{array}$ \\
\hline 1 & Equally important & $\begin{array}{c}\text { Number of storeys, } \\
\text { St }\end{array}$ \\
\hline 3 & Moderately important & $\begin{array}{c}\text { Building materials, } \\
\text { BM }\end{array}$ \\
\hline 5 & Highly important & $\begin{array}{c}\text { Coastal vegetation, } \\
\text { CV }\end{array}$ \\
\hline 7 & Extremely important & $\begin{array}{c}\text { Protective structures, } \\
\text { PS }\end{array}$ \\
\hline
\end{tabular}

Table 3. Matrix of pairwise comparison and the calculated priority vector, $\mathrm{PV}$ for the vulnerability indicators.

\begin{tabular}{|c|c|c|c|c|c|}
\hline $\begin{array}{c}\text { Indi- } \\
\text { cator }\end{array}$ & PS & CV & BM & St & PV \\
\hline PS & 1 & 3 & 5 & 7 & 0.564 \\
\hline CV & 0.333 & 1 & 3 & 5 & 0.263 \\
\hline BM & 0.200 & 0.333 & 1 & 3 & 0.118 \\
\hline St & 0.143 & 0.200 & 0.333 & 1 & 0.055 \\
\hline
\end{tabular}

Based on the above priority vector values, the building vulnerability index (VI) equation is expressed as:

$$
\begin{aligned}
V I= & (0.055 \times S t)+(0.118 \times B M)+(0.263 \times \\
& C V)+(0.564 \times P S)
\end{aligned}
$$

In equation (1), the variable $S t, B M, C V$ and $P S$ refer to the ratings for each vulnerability indicator. For this paper, these ratings as shown in Table 4 are assigned 
according to the parameters' effectiveness in reducing tsunami damage as suggested or evident in literature, as well as the interval of values between 0 (least effective) and 1 (most effectiveness). The resulting VI values for each building are further segregated into quartiles as shown in Table 5.

Table 4. Measurement parameters and assigned ratings for vulnerability assessment.

\begin{tabular}{|c|c|c|c|c|}
\hline$\frac{\text { Parameter }}{\text { Ratings }}$ & $\mathbf{B M}$ & St & PS & CV \\
\hline 0 & & & None & None \\
\hline 0.25 & Timber & & & \\
\hline 0.33 & & $\begin{array}{c}1 \\
\text { storey }\end{array}$ & $\begin{array}{c}\text { Break- } \\
\text { water }\end{array}$ & \\
\hline 0.50 & Masonry & & & $\begin{array}{l}\text { Band } \\
\text { width } \\
<200 \\
\text { m }\end{array}$ \\
\hline 0.67 & & $\begin{array}{c}2 \\
\text { storeys }\end{array}$ & $\begin{array}{l}\text { Single } \\
\text { protec- } \\
\text { tive } \\
\text { structure }\end{array}$ & \\
\hline 0.75 & Steel & & & \\
\hline 1.00 & $\begin{array}{l}\text { Reinforced } \\
\text { concrete }\end{array}$ & $\begin{array}{c}\text { More } \\
\text { than } 2 \\
\text { storeys }\end{array}$ & $\begin{array}{l}\text { Multiple } \\
\text { protec- } \\
\text { tive } \\
\text { structures }\end{array}$ & $\begin{array}{c}\text { Band } \\
\text { width } \\
\geq 200 \\
\mathrm{~m}\end{array}$ \\
\hline
\end{tabular}

Table 5. Vulnerability index values and respective vulnerability levels.

\begin{tabular}{|c|c|c|}
\hline VI values & $\begin{array}{c}\text { Designation and } \\
\text { quartiles }\end{array}$ & Description \\
\hline $0 \leq \mathrm{VI} \leq 0.25$ & $\mathrm{~V} 4$ & $\begin{array}{c}\text { Critically } \\
\text { vulnerable }\end{array}$ \\
\hline $0.25<\mathrm{VI} \leq 0.50$ & $\mathrm{~V} 3$ & $\begin{array}{c}\text { Highly } \\
\text { vulnerable }\end{array}$ \\
\hline $0.50<\mathrm{VI} \leq 0.75$ & $\mathrm{~V} 2$ & Vulnerable \\
\hline $0.75<\mathrm{VI} \leq 1.0$ & $\mathrm{~V} 1$ & Less vulnerable \\
\hline
\end{tabular}

\subsection{Application for the 2018 tsunami events}

Two major tsunami events that occurred in 2018 were selected to test this vulnerability index equation. The first of these is the 28 September Sulawesi tsunami which was triggered following a magnitude 7.5 earthquake $70 \mathrm{~km}$ north of Palu, Indonesia [34]. Despite this identified triggering event, the magnitude and intensity of the resulting tsunami highly suggested that submarine landslides at multiple locations following the earthquake, in addition to high tide during the compound disaster event and liquefied gravity flow further contributed towards the devastating damages observed [34, 35]. Tsunami waves exceeding $10 \mathrm{~m}$ high took more than 5,000 lives including those missing, left 10,679 others injured and tens of thousands more displaced as over 40,000 houses were either destroyed or damaged [1].

The second event chosen for this paper occurred merely three months afterwards in the Sunda Strait region, making it the second major tsunami event in Indonesia in 2018. It is also one of three volcanogenic tsunami from the 271 tsunami events in the past 20 years. The Anak Krakatau volcano which was formed following the Krakatau Islands collapse in 1883 had been showing signs of active Strombolian activities from June to October 2018 with series of explosions and lava flows [36]. These activities reached a climax on $22^{\text {nd }}$ of December 2018 with series of eruptions and showers of incandescent ballistic blocks which led to a moderate collapse in the western and southern section of the volcano $[37,38]$. Tsunami waves up to approximately $25 \mathrm{~m}$ were recorded on the surrounding islands, and runup in coastal cities and town near the region reached up to $15 \mathrm{~m}$ high [39]. This event recorded relatively lower deaths at 437 , but the population injured were significantly higher at over 31,000 people. Also in contrast, 2,844 houses or buildings were damaged in this event [1].

Additional information required for the vulnerability assessment that is not provided in the field survey data such as coastal vegetation cover, protective structures and distance from shoreline are identified and gathered visually from available satellite image with recording date preceding the tsunami events. For Palu city, satellite images used for reference were recorded on August 2018, while for Banten and Lampung area, the satellite images dated back to October 2018. Measurements for buildings' distance in particular are done perpendicular to the shoreline, with visible vegetation cluster in its direct path considered and measured for the $\mathrm{CV}$ indicator. Polygons are drawn for ease of measurement due to irregularly shaped shorelines. Sample measurement is shown in the figure below.

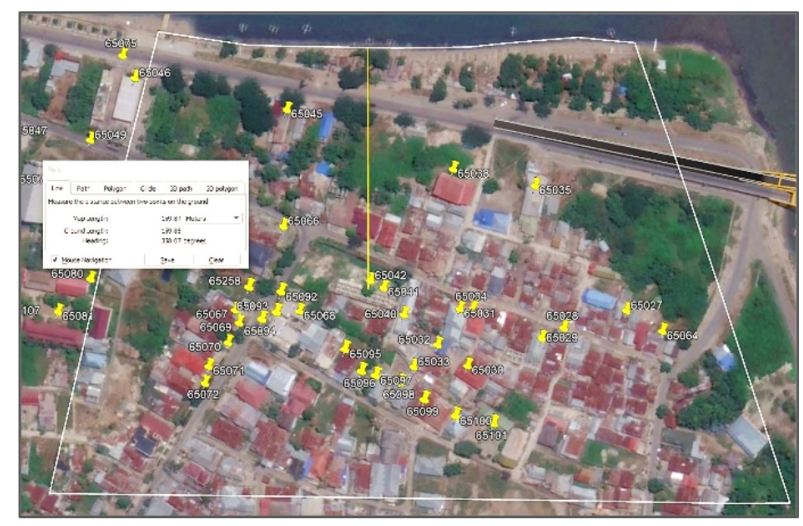

Fig 1. Marking buildings' locations based on coordinates provided in field survey data sets, measuring distances and identifying surrounding features.

\section{Results}

Data set from two field surveys were used as the source for inundation depth measurements, building 
typologies' information and building damaged data. The field survey for Sulawesi tsunami in Palu was conducted from 13 to 17 November 2018, while the field survey for the Sunda Strait tsunami was conducted between 24 December 2018 to 3 January 2019 at Banten and Lampung $[40,41]$. Based on the data set provided by both studies, inundation depth profile as shown in Figure 2 can be observed. The Sulawesi tsunami disaster recorded inundation depths for buildings ranging between $0.1-3.65 \mathrm{~m}$, with a median of $0.98 \mathrm{~m}$. On the other hand, the Sunda Strait tsunami recorded inundation depths ranging from $0.2-6.6 \mathrm{~m}$, as well as a median depth of $2.72 \mathrm{~m}$.

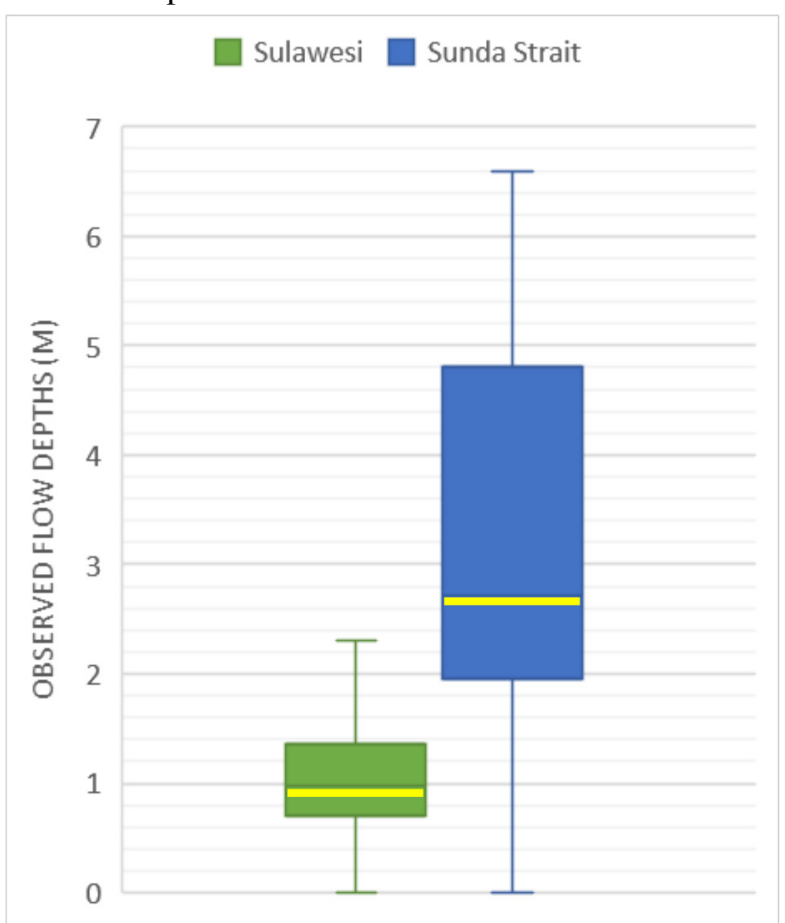

Fig 2. Inundation depth ranges for both tsunami events used as reference in this paper.

Considering the two data sets did not employ the same scale to categorise tsunami damage on buildings, the following re-categorisation is also done for all data gathered to harmonise the data and for ease of comparison. The designation for each grade as listed in Table 6 are adapted based on descriptions provided in both field surveys, as well as common classification in literatures [42].

\subsection{Vulnerability profile}

Application of the proposed vulnerability index equation for buildings affected by the two tsunami events yielded distribution as shown in Figure 3. In total 468 buildings were assessed, 371 of which were affected by the Sulawesi tsunami event, while 97 others were damaged by the Sunda Strait event. No building in either event could be identified as being "less vulnerable", likely contributed by the fact that only $4 \%$ of buildings in Palu were engineered reinforced concrete buildings, while majority in both events were of confined masonry construction [40, 41]. Across affected regions, majority of the buildings were categorised as V3 or highly vulnerable owing to the lack of protective features in between the buildings and the sea, particularly coastal vegetation. It can be noted that for the most part, road and buildings at both locations were built on elevated ground, and/or separated from the sandy shores by rocky levees and low seawalls.

Table 6. Damage state categorisation for buildings damaged in both tsunami events and the equivalent used in this paper.

\begin{tabular}{|c|c|c|}
\hline $\begin{array}{c}\text { Paulik et al. } \\
{[40]}\end{array}$ & $\begin{array}{l}\text { Syamsidik et } \\
\text { al. [41] }\end{array}$ & $\begin{array}{l}\text { Re-categorised } \\
\text { grades }\end{array}$ \\
\hline \multirow[t]{2}{*}{$\begin{array}{l}\text { DL0 (No } \\
\text { damage) }\end{array}$} & $\begin{array}{l}\text { DC0 (No } \\
\text { damage) }\end{array}$ & $\begin{array}{l}\text { DS1 (Flooded only; } \\
\text { No damages } \\
\text { sustained) }\end{array}$ \\
\hline & $\begin{array}{l}\text { DC1 (Minor } \\
\text { damage) }\end{array}$ & $\begin{array}{l}\text { DS2 (Minor damages } \\
\text { including external } \\
\text { scouring, damaged } \\
\text { roof) }\end{array}$ \\
\hline $\begin{array}{l}\text { DL1 (Partial } \\
\text { damage, } \\
\text { repairable) }\end{array}$ & $\begin{array}{l}\text { DC2 (Moderate } \\
\text { damage) }\end{array}$ & $\begin{array}{c}\text { DS3 (Moderate } \\
\text { damages; damaged } \\
\text { walls, door, windows. } \\
\text { Repairable) }\end{array}$ \\
\hline $\begin{array}{l}\text { DL2 (Partial } \\
\text { damage, } \\
\text { unrepairable) }\end{array}$ & $\begin{array}{l}\text { DC3 (Major } \\
\text { damage) }\end{array}$ & $\begin{array}{l}\text { DS4 (Major damages; } \\
\text { damages primary } \\
\text { members e.g. } \\
\text { columns. Requires } \\
\text { major repairs) }\end{array}$ \\
\hline $\begin{array}{c}\text { DL3 } \\
\text { (Complete } \\
\text { damage) }\end{array}$ & $\begin{array}{c}\text { DC4 } \\
\text { (Completely or } \\
\text { washed away) }\end{array}$ & $\begin{array}{l}\text { DS5 (Collapse or } \\
\text { washed away; Total or } \\
\text { irreparable damages) }\end{array}$ \\
\hline
\end{tabular}

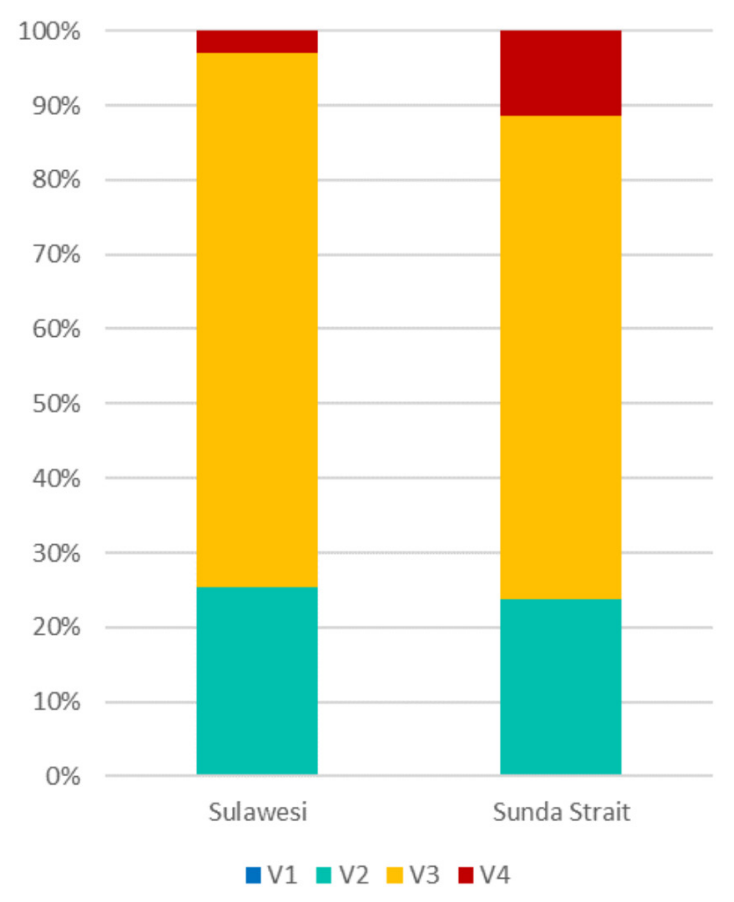

Fig 3. Vulnerability distribution for buildings affected by the 2018 Sulawesi and Sunda Strait tsunami events. V1 V4 refer to vulnerability levels as described in Table 5. 
While these may have been designed to protect landward area from coastal flooding or high tide, in this paper they are counted towards reducing tsunami vulnerability. Additionally, majority of the buildings were low-rise residential buildings made of timber or masonry, hence the relatively high vulnerability ratings. Over $10 \%$ of buildings in the Banten and Lampung region were observed as being critically vulnerable, while only 3\% could be categorised similarly in Palu.

\subsection{Correlation to hazard intensity and damages observed}

Similar to the vulnerability distribution, a frequency heatmap in Figure 4 is used to visually represent the relationship between hazard intensity (inundation depth), vulnerability levels, and damages recorded. Inundation depths were grouped into eight grades with the intervals shown in the figure. From 0 to $2 \mathrm{~m}$ depth, the intervals were $0.5 \mathrm{~m}$ each to allow for a better observation of damage distribution at low flow depths and as deemed appropriate considering the data available. Otherwise, for flow depths above $2 \mathrm{~m}$, the interval for each grade was $1 \mathrm{~m}$. These intervals were categorised in such a way since building damages have been found to be certain (DS2 and above) when the inundation depth is above $2 \mathrm{~m}$ regardless of the building typology [4]. Furthermore, at inundation depth of $5 \mathrm{~m}$ and above, there is significantly higher probability for complete damage or for buildings to be washed away particularly for timber and masonry buildings [43, 44].

In this case for Palu, Banten and Lampung, most buildings with vulnerability classes 2,3 and 4 suffered damages ranging from DS1 (flooded only) to DS3 (moderate damages) when inundation depth is below 1.0 $\mathrm{m}$, except for a number of cases in Palu where the buildings were severely damaged or destroyed. As flow depth increases beyond $1 \mathrm{~m}$, the proportion of buildings sustaining major damages markedly increased, as expected based on various tsunami intensity models previously. While the findings presented in Figure 4 cannot be claimed as conclusive and uncertainties remain, such as the degree of damages or vulnerabilities induced by event(s) preceding the tsunami, a clear trend can be observed in the figure whereby damage severity increases quiet linearly with vulnerability and hazard intensity. DS4 (major damages) dominates at flow depths of $1.5 \mathrm{~m}$ to $4 \mathrm{~m}$, while above that majority of the buildings across all vulnerability classes collapsed or were washed away. To further demonstrate the discrepancies caused by the preceding tsunami triggering event, we take the example of inundation depths grade 1 and 2 (below $1.0 \mathrm{~m}$ ), whereby buildings in Palu appeared to have sustained damages of DS4 and DS5. In the Sunda Strait region, only DS1 (flooded only) were recorded for buildings inundated at these lower depths. This is despite the fact that the buildings in Palu were mostly located within $100 \mathrm{~m}$ to $180 \mathrm{~m}$ from the shoreline, while in Lampung and Banten the buildings were mostly less than $100 \mathrm{~m}$ away. It is thus important to note that the compounding effects of earthquake, soil liquefaction and the tsunami during the 2018 event in Palu significantly intensified the damages observed.

Comparing damage probabilities presented in fragility curves for the two events have found that the distribution of damages in Figure 4 reflected the estimated probabilities fairly well $[41,45]$. While direct comparison between fragility curves and observations from Figure 4 below may not provide the most accurate or desirable validation for the vulnerability index, interesting observations can still be made which may warrant further exploration.

Based on the fragility curves for confined masonry buildings presented in [41] for the Sunda Strait event, at under $1 \mathrm{~m}$ flow depth the probability distribution is partially reflected since moderate damage (DS3)

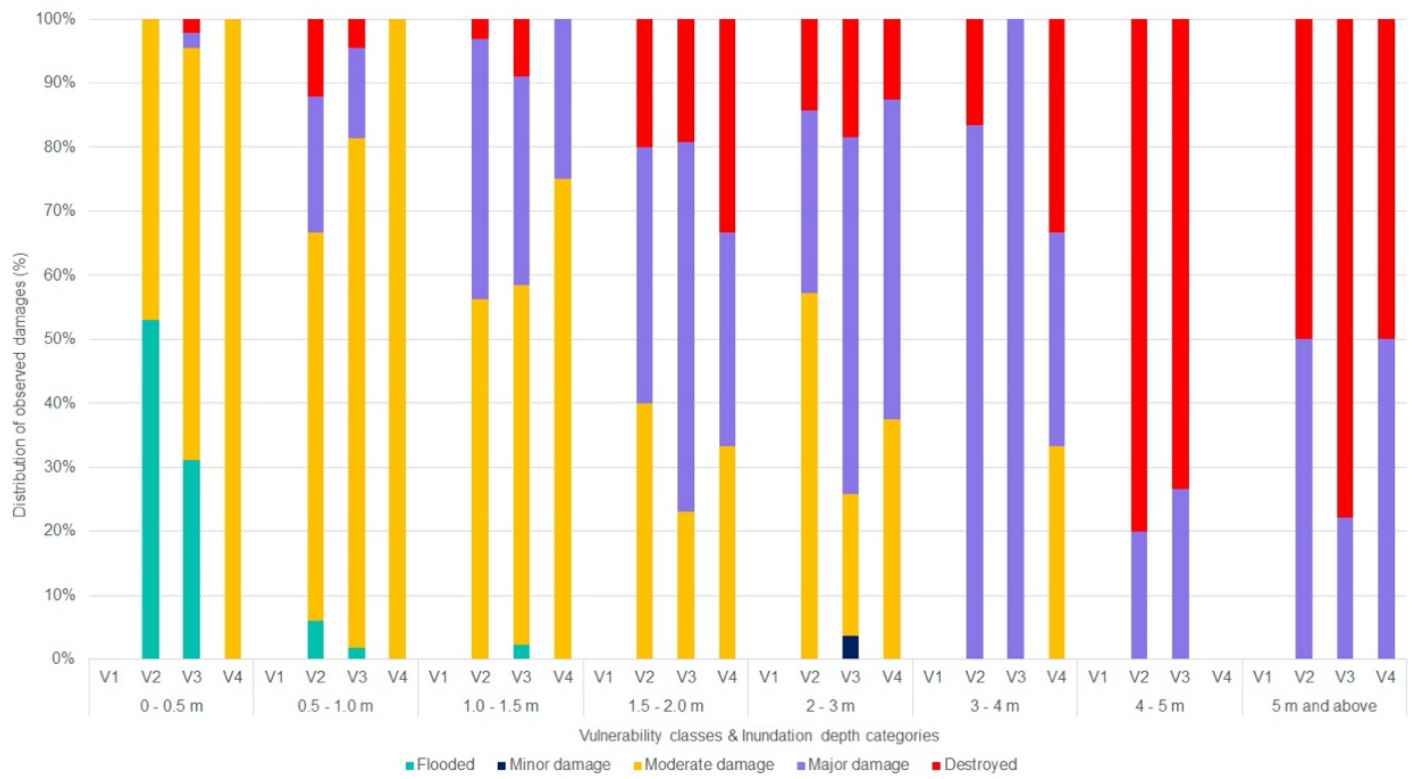

Fig 4. Distribution of building damages for 2018 Palu and Sunda Strait tsunami categorised by flow depth and vulnerability classes. 
accounted for the majority of the buildings even at vulnerability class $\mathrm{V} 2$, with DS1 being prominent at under $0.5 \mathrm{~m}$, while DS4 and DS5 are accountable at a lesser proportion as well. Meanwhile, for the Sulawesi tsunami event, the fragility curve available for buildings with similar typology showed better correlation particularly for minor to moderate, as well as major damages distribution for class V2 and V3 buildings [45]. This is most likely due to higher number of field survey data being sampled and utilised in the analysis, as mentioned in section 4.1.

As for timber buildings damaged by the Sunda Strait tsunami, probability distribution presented in [45] for flow depths under $2 \mathrm{~m}$ were reflected quite well especially in reference to buildings with vulnerability class V4 in the figure. For flow depths of $2 \mathrm{~m}-3 \mathrm{~m}$, significant differences were noticeable however with moderate damages still being significant for class V4. However, as the flow depth increases, the probable damages for timber buildings were again reflected quite accurately in the distribution for class V4 due to the fact that inundation during the Sulawesi tsunami event did not exceed $3 \mathrm{~m}$ in depth.

Another interesting observation in relation to the topic of this paper is the potential effectiveness of coastal protection, in particular coastal vegetation. In both events, coastal vegetation that may function as effective protective are relatively scarce. However, in areas where vegetation is available, some degree of protection can be observed. Figure 5(a) shows the before and after photo of two masonry residential buildings both with vulnerability class V2. Building B68 sustained moderate damage (DS3) despite being inundated by over $2.5 \mathrm{~m}$ of seawater and being closer to the shoreline, while building B67 suffered major damage, even though the inundation depth recorded at its location was only $1.44 \mathrm{~m}$ high and the building was twice as far from the shores. The only other difference in this case is the width and density of vegetation in the direct wave path between the buildings and the shoreline. The second snapshot in Figure 5(b) shows another building in Kabupaten, South Lampung. The building identified as B97 (in the field survey data set) is located approximately $80 \mathrm{~m}$ from the shoreline. However, inundation depth recorded at its location is low at $0.5 \mathrm{~m}$, and no damage was recorded for the vulnerability class 2 building. Based on the slight difference in vegetation cover, it is highly probable that the band of trees effectively protected the building from the incoming waves.

\section{Conclusion}

This paper provides a discussion for the potential, development, and application of a tool to assess vulnerability level of buildings in at-risk areas towards tsunami-induced building damages via a set of generalisable vulnerability indicators. Subsequently, the links that can be observed between hazard intensity, vulnerability class and impacts from the tsunami were discussed. The proposed index is developed with the aim of improving usability of presently available
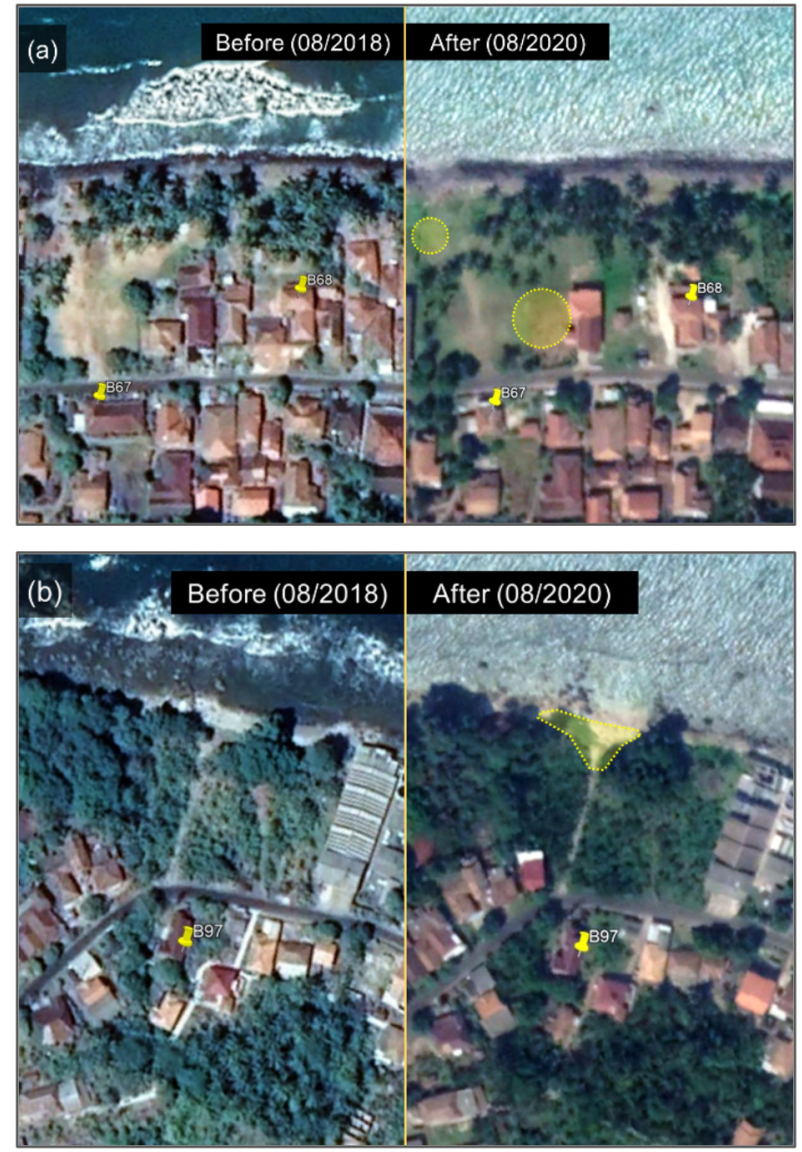

Fig 5. (a) Before and after snapshot for building B67 and B68. (b) Snapshot of before and after for building B97. Both cases are from the Sunda Strait event. Visible changes in vegetation are highlighted in yellow. Building damage is also visible for building B67 in figure (a).

tsunami risk assessment tools and models, while also maintaining simplicity and relative accuracy in both exante and ex-post usage. However, much like fragility curves, the accuracy of damage distribution as a result of the interaction between tsunami hazard intensity and vulnerability levels is influenced greatly by diversity, quantity and quality of field data. For this paper, the probable damages estimated in some cases based on the damage distribution rely heavily on data from a particular event, at a particular location. Due to this, addition of data from different localities and tsunami events may be able to address this inaccuracy. Furthermore, the index in its current state has potential for improvements which may be achievable via:

i. application of expert opinions' survey similar to PTVA's revision for the purpose of reviewing and refining vulnerability indicators used in the index as well as the weightages assigned to each.

ii. inclusion of data sets from the 2011 Japan tsunami where abundance of data are available. Comparison can be done with cities where all vulnerability indicators used in this study can be accounted for, and thus may also offer better insight in terms of drawing conclusive correlation between all independent, moderating and dependent variables as used in this paper. 
iii. the significance of each vulnerability indicator as a moderating variable component may also be statistically tested and proven to reduce uncertainties in the index.

iv. consideration can be given to other indicators that are reasonably generalisable to be included in the index such as building row and distance from shoreline, where possible.

Additionally, in future work, this vulnerability index can be harmonised with, and incorporated into a descriptive tsunami intensity scale to facilitate better tsunami risk understanding, assessment and communication at all levels particularly among community stakeholders.

\section{References}

1. National Geophysical Data Center / World Data Service: NCEI/WDS Global Historical Tsunami Database. NOAA National Centers for Environmental Information. doi:10.7289/V5PN93H7 (Accessed on 20 July 2021)

2. CRED, D. Guha-Sapir, EM-DAT: The Emergency Events Database. https://public.emdat.be/data (Accessed on 20 July 2021)

3. UNISDR, Words into Action guidelines: National Disaster Risk Assessment (2017)

4. A. Suppasri, E. Mas, I. Charvet, R. Gunasekera, K. Imai, Y. Fukutani, Y. Abe and F. Imamura, Nat. Hazards 66, 319-341 (2013)

5. I. Charvet, I. Ioannou, T. Rossetto, A. Suppasri and F. Imamura, Nat. Hazards 73, 951-973 (2014)

6. R. de Risi, K. Goda, N. Mori and T. Yasuda, Stoch. Environ. Res. Risk Assess. 31, 1253-1269 (2016)

7. Y. Xiong, Q. Liang, H. Park, D. Cox and G. Wang, Coast. Eng. 144, 1-14 (2019)

8. J. Bonacho and C.S. Oliveira, Int. J. Disaster Risk Reduct. 31, 275-280 (2018)

9. H. Park, M.S. Alam, D.T. Cox, A. R. Barbosa and J.W. van de Lindt, Int. J. Disaster Risk Reduct. 35, 101076 (2019)

10. M. Mück, H. Taubenböck, J. Post, S. Wegscheider, G. Strunz, S. Sumaryono and F.A. Ismail, Nat. Hazards 68, 97-114 (2013)

11. F. Dall'Osso, D. Dominey-Howes, C. Tarbotton, S. Summerhayes and G. Withycombe, Nat. Hazards 83, 1229-1256 (2016)

12. P. Srivihok, K. Honda, A. Ruangrassamee, V. Muangsin, P. Naparat, P. Foytong, N. Promdumrong, P. Aphimaeteethomrong, A. Intavee, J.E. Layung and T. Kosin, Cont. Shelf Res. 79, 3-15 (2014)

13. K. Goda and J. Song, Stoch. Environ. Res. Risk Assess. 30(8), 2271-2285 (2015)

14. O.D. Cardona, M.K. van Aalst, J. Birkmann, M. Fordham, G. McGregor, R. Perez, R.S. Pulwarty, E.L.F. Schipper, and B.T. Sinh, Determinants of risk: exposure and vulnerability, in Managing the Risks of Extreme Events and Disasters to Advance Climate Change Adaptation [C.B. Field, V. Barros, T.F. Stocker, D. Qin, D.J. Dokken, K.L. Ebi, M.D. Mastrandrea, K.J. Mach, G.-K. Plattner, S.K. Allen, M. Tignor, and P.M. Midgley (eds.)] (Cambridge
University Press, Cambridge, UK, and New York, NY, USA, pp. 65-108, 2012)

15. GFDRR/World Bank, Understanding risk: review of open source and open access software packages available to quantify risk from natural hazards (World Bank Group, Washington, DC, 2014)

16. B. Wisner and H.R. Luce, GeoJournal 30(2), 127140 (1993)

17. T. Cannon, Vulnerability analysis, livelihoods and disasters, in Risk 21: Coping with Risks Due to Natural Hazards in the 21st Century [W.J. Ammann, S. Dannenmann, and L. Vulliet (eds.)] (Taylor and Francis Group, London, UK, pp. 41-49, 2006)

18. H. Park, D.T. Cox and A.R. Barbosa, Coast. Eng. 122, 10-26 (2017)

19. K. Goda and R. de Risi, Int. J. Disaster Risk Reduct. 28, 539-554 (2018)

20. S. Karafagka, S. Fotopoulou and K. Pitilakis, Soil Dyn. Earthq. Eng. 112, 118-137 (2018)

21. S. Belliazzi, G.P. Lignola, M. di Ludovico and A. Prota, Structures 31, 68-79 (2021)

22. G.S. Leonard, N. Evans, G. Prasetya, W.S.A. Saunders, L. Pearse, D. Monastra, and S. Fraser, Scoping study for evaluating the tsunami vulnerability of New Zealand buildings for use as evacuation structures, GNS Science Report 2011/36 39 p. (2011)

23. R.A. Darlymple and D.L. Kriebel, Lessons in engineering from the tsunami in Thailand in The Bridge Vol. 35, No. 2, G. Bugliarello (ed.) (National Academy of Sciences, Washington, DC, 2005) pp. 4-13

24. S. Medina, J. Lizarazo-Marriaga, M. Estrada, S. Koshimura, E. Mas and B. Adriano, Eng. Struct. 196, 109309 (2019)

25. R.S.M. Samarasekara, J. Sasaki, M. Esteban and H. Matsuda, Int. J. Disaster Risk Reduct. 23, 80-92 (2017)

26. R. de Risi, K. Goda, T. Yasuda and N. Mori, Earth Sci. Rev. 166, 64-82 (2017)

27. J.C.L. Bayas, C. Marohn, G. Dercon, S. Dewi, H.P. Piepho, L. Joshi, M. van Noordwijk and G. Cadisch, Influence of coastal vegetation on the 2004 tsunami wave impact in west Aceh in Proceedings of the National Academy of Sciences of the United States of America 108(46), 1861218617 (2011)

28. A.M. Hashim, SM.P. Catherine and H. Takaijudin, Res. J. Appl. Sci. Eng. Technol. 5(18), 4483-4488 (2013)

29. R. Omira, M.A. Baptista, J.M. Miranda, E. Toto, V. Catita and J. Catalao, Nat. Hazards 54, 75-95 (2010)

30. H. Takagi and J.D. Bricker, Coast. Eng. 56(4), 1450018 (2014)

31. K. Harada and F. Imamura, Effects of coastal forest on tsunami hazard mitigation - a preliminary investigation, in: K. Satake (eds) Tsunamis. Advances in Natural and Technological Hazards Research, Vol. 23, Springer, Dordrecht (2005)

32. H. Ismail, A.K. Abd Wahab and N.E. Alias, Nat. Hazards 63, 939-963 (2012)

33. T.L. Saaty, Eur. J. Oper. Res. 48, 9-26 (1990) 
34. K. Nakata, A. Katsumata and A. Muhari, Earth Planets and Space 72:44 (2020)

35. A.R. Gusman, P. Supendi, A.D. Nugraha, W. Power, H. Latief, H. Sunendar, S. Widiyantoro, Daryono, S.H. Wiyono, A. Hakim, A. Muhari, X. Wang, D. Burbidge, K. Palgunadi, I. Hamling and M. R. Daryono, Geophys. Res. Lett. 46(15), doi: 10.1029/2019GL082717 (2019)

36. Global Volcanism Program, Report on Krakatau (Indonesia) (Crafford, A.E., and Venzke, E., eds.). Bulletin of the Global Volcanism Network, 43:10, Smithsonian Institution (2018)

37. Global Volcanism Program, Report on Krakatau (Indonesia) (Krippner, J.B., and Venzke, E., eds.). Bulletin of the Global Volcanism Network, 44:3, Smithsonian Institution (2019)

38. L. Ye, H. Kanamori, L. Rivera, T. Lay, Y. Zhou, D. Sianipar and K. Satake, Sci. Adv. 6(3), eaaz1377 (2020)

39. T. Takabatake, T. Shibayama, M. Esteban, H. Achiari, N. Nurisman, M. Gelfi, T.A. Tarigan, E.R. Kencana, M.A.R. Fauzi, S. Panalaran, A.S. Harnantyari, T.O. Kyaw, Coast. Eng. J. 61, 423443 (2019)

40. R. Paulik, A. Gusman, J.H. Williams, G.M. Pratama, S.L. Lin, A. Prawirabhakti, K. Sulendra, M.Y. Zachari, Z.E.D. Fortuna, N.B.P. Layuk and N.W.I. Suwarni, Pure Appl. Geophys. 176, 33053321 (2019)

41. Syamsidik, Benazir, M. Luthfi, A. Suppasri and L.K. Comfort, Nat. Hazards Earth Syst. Sci. 20, 549-565 (2020)

42. A. Suppasri, I. Charvet, J. Macabuag, T. Rossetto, N. Leelawat, P. Latcharote and F. Imamura, Building Damage Assessment and Implications for Future Tsunami Fragility Estimations in M. Esteban, H. Takagi and T. Shibayama (eds.) Handbook of Coastal Disaster Mitigation for Engineers and Planners (Butterworth-Heinemann, Oxford, 2015)

43. S. Reese, B.A. Bradley, J. Bind, G. Smart, W. Power and J. Sturman, Earth Sci. Rev. 107, 156$173(2011)$

44. K.I.U. Nanayakkara and W.P.S. Dias, Nat. Hazards 80, 471-486 (2016)

45. E. Lahcene, I. Ioannou, A. Suppasri, K. Pakoksung, R. Paulik, Syamsidik, F. Bouchette and F. Imamura, Nat. Hazards Earth Syst. Sci. 21, 2313-2344 (2021) 